\title{
Sympathetic-correlated c-Fos expression in the neonatal rat spinal
} cord in vitro

\author{
Chun-Kuei Su*1, Chiu-Ming Ho², Hsiao-Hui Kuo, ${ }^{1,2}$, Yu-Chuan Wen ${ }^{1}$ and \\ Chok-Yung Chai ${ }^{1,3}$
}

\begin{abstract}
Address: ${ }^{1}$ Institute of Biomedical Sciences, Academia Sinica, Taipei 115, Taiwan, Republic of China ${ }^{2}$ Department of Anesthesiology, Taipei Veterans General Hospital and National Yang-Ming University, Taipei 112, Taiwan, Republic of China and ${ }^{3}$ Department of Physiology and Biophysics, National Defense Medical Center, Taipei 114, Taiwan, Republic of China

Email: Chun-Kuei Su* - csu@ibms.sinica.edu.tw; Chiu-Ming Ho - cmho@vghtpe.gov.tw; Hsiao-Hui Kuo - hhkuo025@yahoo.com.tw; YuChuan Wen - lucy49_win@yahoo.com.tw; Chok-Yung Chai - cychai@ibms.sinica.edu.tw

* Corresponding author
\end{abstract}

Published: I May 2009

Journal of Biomedical Science 2009, 16:44 doi:10.1186/1423-0127-16-44

This article is available from: http://www.jbiomedsci.com/content//6/I/44

(c) 2009 Su et al; licensee BioMed Central Ltd.

This is an Open Access article distributed under the terms of the Creative Commons Attribution License (http://creativecommons.org/licenses/by/2.0), which permits unrestricted use, distribution, and reproduction in any medium, provided the original work is properly cited.
Received: 27 November 2008

Accepted: I May 2009

\begin{abstract}
An isolated thoracic spinal cord of the neonatal rat in vitro spontaneously generates sympathetic nerve discharge (SND) at $\sim 25^{\circ} \mathrm{C}$, but it fails in SND genesis at $\leq 10^{\circ} \mathrm{C}$. Basal levels of the c-Fos expression in the spinal cords incubated at $\leq 10^{\circ} \mathrm{C}$ and $\sim 25^{\circ} \mathrm{C}$ were compared to determine the anatomical substrates that might participate in SND genesis. Cells that exhibited c-Fos immunoreactivity were virtually absent in the spinal cords incubated at $\leq 10^{\circ} \mathrm{C}$. However, in the spinal cords incubated at $\sim 25^{\circ} \mathrm{C}$, c-Fos-positive cells were found in the dorsal laminae, the white matter, lamina $X$, and the intermediolateral cell column (IML). Cell identities were verified by double labeling of c-Fos with neuron-specific nuclear protein (NeuN), glial fibrillary acidic protein (GFAP), or choline acetyltransferase (ChAT). The c-Fos-positive cells distributed in the white matter and lamina $X$ were NeuN-negative or GFAP-positive and were glial cells. Endogenously active neurons showing c-Fos and NeuN double labeling were scattered in the dorsal laminae and concentrated in the IML. Double labeling of c-Fos and ChAT confirmed the presence of active sympathetic preganglionic neurons (SPNs) in the IML. Suppression of SND genesis by tetrodotoxin (TTX) or mecamylamine (MECA, nicotinic receptor blocker) almost abolished c-Fos expression in dorsal laminae, but only mildly affected c-Fos expression in the SPNs. Therefore, c-Fos expression in some SPNs does not require synaptic activation. Our results suggest that spinal SND genesis is initiated from some spontaneously active SPNs, which are capable of TTX- or MECA-resistant cFos expression.
\end{abstract}

\section{Background}

Autonomous generation of tonic sympathetic activity is fundamental to normal visceral functions. The primary source for sympathetic tone generation is the brain stem [1-4]. However, in neonatal rats, three or fewer thoracic spinal cord segments contain sufficient neural elements for spontaneous generation of sympathetic nerve discharge (SND; [5]). In vitro studies have reported that some sympathetic preganglionic neurons (SPNs) are spontaneously active in the absence of extraspinal inputs [6-9]. These in vitro observations are consistent with the in vivo observations that, being deprived of supraspinal 
inputs, isolated spinal cords generate substantial amounts of SND in adult animals [10-14]. Although an isolated spinal cord could generate SND under certain pathophysiological conditions, the spinal neurons responsible for SND genesis were largely unknown.

Findings obtained from the studies of neural elements involved in sympathetic regulation at the level of the spinal cord could provide clues to elucidate the anatomical substrates underlying spinal SND genesis. It was found that peripheral visceral afferents project to the gray matter of the spinal cord at both superficial (lamina I and II) and deep layers (laminae V, VII, and X) [15-17], wherein sympathetic interneurons are concentrated in the deeper layers [18-20] and scattered in more dorsal laminae [21,22]. Moreover, a group of GABAergic sympathetic interneurons is located in the central gray matter or lamina $X$ [23]. All these studies suggest that sympathetic-correlated neurons are mainly distributed in medial dorsal parts of the spinal cord.

Using a reduced preparation that only retained splanchnic sympathetic nerve-thoracic spinal cord, we demonstrated that one prerequisite condition for in vitro SND genesis is to incubate the spinal cord at an ambient temperature $\geq$ $20^{\circ} \mathrm{C}[24]$. The optimal temperature for the cord to generate SND in the splanchnic nerves is $24.5 \pm 1^{\circ} \mathrm{C}[5,24]$. However, because activities of different sympathetic nerves originate in nonoverlapping spinal segments $[5,25,26]$, whether the thoracic cord in vitro can generate SNDs in other sympathetic nerves was not clear.

The expression of c-Fos protein is often used as a marker of neural activity [27]. Different experimental paradigms have been used to stimulate c-Fos expression in the central nervous system to elucidate the involved anatomical substrates [28-35]. In this study, we first established that cervical and splanchnic sympathetic nerves share a common temperature-dependent scheme for SND genesis. We then incubated the spinal cord at ambient temperatures favorable or unfavorable for SND genesis, and explored the resulting c-Fos expression patterns. Manipulations of cFos expression patterns were achieved by applications of tetrodotoxin (TTX) to block action potential generation, or applications of mecamylamine (MECA) to exert a broad-spectrum blockade of nicotinic receptor activities that would attenuate SND [36]. For comparisons, a negative control of drug effects on c-Fos expression was achieved by applications of kynurenate (KYN), which did not suppress SND genesis in the cord [37]. By determining SND-correlated c-Fos expression patterns, we aimed to elucidate the anatomical substrates underlying SND genesis.

\section{Materials and methods General procedures}

Neonatal Sprague Dawley rats were used in this study (16 days old; $n=99$ ). All protocols were approved by the Institutional Animal Care and Utilization Committee of Academia Sinica (Protocol\#: PRaIBMSC2003014). Surgical procedures were as previously described [24]. Briefly, halothane-anesthetized neonates were promptly decerebrated and transcardially perfused with $\sim 4^{\circ} \mathrm{C}$ artificial cerebrospinal fluid (aCSF; in mM: $128 \mathrm{NaCl}, 3 \mathrm{KCl}, 1.5$ $\mathrm{CaCl}_{2}, 1.0 \mathrm{MgSO} 4,24 \mathrm{NaHCO}_{3}, 0.5 \mathrm{NaH}_{2} \mathrm{PO}_{4}, 30 \mathrm{D}$-glucose, and 3 ascorbate; equilibrated with 95\% $\mathrm{O}_{2}-5 \%$ $\mathrm{CO}_{2}$ ). After dissection, thoracic spinal cord segments (T1T12) were retained. The cervical sympathetic nerve was prepared by freeing a stub of the right paravertebral sympathetic trunk from surrounding connective tissue at the level of the first and second ribs. The splanchnic nerve, mainly containing preganglionic fibers, was easily identified by its innervation to the celiac ganglion located adjacent to the adrenal gland.

\section{Neural recordings and signal analysis}

The nerve-cord preparation was kept in a thermo-controlled bath chamber containing $30 \mathrm{ml}$ freshly oxygenated aCSF. Compound action potentials generated from the cervical and splanchnic sympathetic nerves were recorded using suction electrodes. Neural signals were amplified, filtered at a bandpass of 0.1-1 kHz (DAM50; World Precision Instruments, Sarasota, Florida, USA), and stored on a tape recorder (Neuro-Corder DR-890; CygnusTechnology Inc., Delaware Water Gap, Pennsylvania, USA). The processing of signals followed methods previously described [5]. Briefly, SND signals were integrated using a custom-made leaky integrator (discharging time constant: $15 \mathrm{~ms}$ ) to display the SND envelope. For quantitative evaluation of its oscillating patterns, signals of the SND envelope were digitized (Digidata 1322A; Axon Instruments; Molecular Devices Corp, Sunnyvale, California, USA), and sampled at $0.4 \mathrm{kHz}$ to obtain 16 data segments with each registering $40.96 \mathrm{~s}$. The power spectra of the SND envelope were constructed using Axograph (version 4.9; Axon Instruments). The spectral components that are truly attributed to neural activity were extracted by subtracting from the spectra of background noise, which was determined by adding $100 \mathrm{mM} \mathrm{KCl}$ into bath solution for depolarization-blockade of action potential generation. Power spectra of each experiment were normalized to their peak power at $\sim 1 \mathrm{~Hz}$, which allowed data pooling from individual experiments to acquire average power spectra.

\section{Drugs and drug application}

Drugs were purchased from Sigma (St. Louis, Missouri, USA) and dissolved in water to prepare concentrated solutions. To avoid spontaneous SND genesis that might lead 
to endogenous c-Fos synthesis at $25^{\circ} \mathrm{C}$, drugs were applied by adding an aliquot of concentrated solutions directly to the bath solution when the cord was incubated at $\leq 10^{\circ} \mathrm{C}$. Suppression of SND genesis was attained by application of $0.5 \mu \mathrm{M}$ tetrodotoxin citrate (TTX) or application of $20 \mu \mathrm{M}$ mecamylamine hydrochloride (MECA) to block endogenously active nicotinic receptors [36]. In some experiments, application of $800 \mu \mathrm{M}$ kynurenate (KYN) was used for a broad-spectrum blockade of ionotropic glutamate receptors. After drug applications, the incubation temperature was taken up to $25^{\circ} \mathrm{C}$ to allow cFos synthesis for $3 \mathrm{~h}$ under in vitro conditions.

\section{Immunohistochemistry}

After incubation under different experimental conditions, the spinal cords were immersed in $4 \%$ paraformaldehyde overnight and cryoprotected with $30 \%$ sucrose in $0.1 \mathrm{M}$ phosphate buffer saline ( $\mathrm{pH} 7.4)$. Frozen tissue blocks were routinely cut into transverse (T3/T6/T9) or horizontal sections (T7-T8) at 25-40 $\mu \mathrm{m}$ thicknesses. In some experiments, sections of other thoracic spinal cord segments were sampled for comparative purposes. Two series of immunohistochemical protocols, the diaminobenzidine $(\mathrm{DAB})$ reaction or conjugated-fluorescent markers, were used to reveal c-Fos protein. Pretreatment of freefloating sections to quench endogenous peroxidase activity was performed following procedures as described in other studies [38-40]. The blocking of nonspecific staining and the enhancement of immunoreagent penetration were achieved by pretreating sections in $10 \%$ normal goat serum containing $0.3 \%$ Triton X-100. Sections were then incubated in affinity-purified rabbit anti-c-Fos polyclonal antiserum (1:3000; sc-52, Santa Cruz Biotechnology Inc, Santa Cruz, California, USA) for $48 \mathrm{~h}$ at $4{ }^{\circ} \mathrm{C}$, followed by incubation with the secondary antibody, biotinylated goat anti-rabbit IgG (1:150; Vector Laboratories Inc., Burlingame, California, USA) for $1 \mathrm{~h}$ at $4^{\circ} \mathrm{C}$. Immunoreactive signals were further amplified by $\mathrm{ABC}$ solution $(1: 100$; Vector Laboratories Inc.) and revealed by a nickel-intensified $\mathrm{DAB}$ reaction, with peroxide generated by glucose oxidase [41]. This was accomplished by incubating sections in the DAB-nickel-glucose-oxidase solution for 0.5$2 \mathrm{~min}$. At the end of the DAB reaction, sections were washed and mounted onto gelatin-coated slides. In some experiments, sections were counter-stained with cresyl violet before being dehydrated in ethanol, cleared in xylene, and coverslipped.

Another series of tissue sections were prepared for the double labeling of c-Fos with choline acetyltransferase (ChAT), glial fibrillary acidic protein (GFAP), or neuronspecific nuclear protein (NeuN). Sections were incubated in a mixture of two primary antisera for $48-72 \mathrm{~h}$ at $4^{\circ} \mathrm{C}$. The mixture of two primary antisera in $2 \%$ normal donkey serum contained affinity-purified rabbit anti-c-Fos poly- clonal antiserum (1:4000; Santa Cruz Biotechnology Inc.) and affinity-purified goat anti-ChAT polyclonal antiserum (1:100; AB144P, Chemicon, Millipore Corp, Billerica, Massachussetts), mouse anti-GFAP monoclonal antiserum (1:1000; MAB360, Chemicon) or mouse anti-NeuN monoclonal antiserum (1:1000; MAB377, Chemicon). Specificity of the polyclonal primary antisera against c-Fos or ChAT for immunohistochemical staining in the rat spinal cord has been demonstrated in previous studies $[35,42]$. Fluorescent-marker-conjugated secondary antisera were purchased from Chemicon. Sections were incubated for $2 \mathrm{~h}$ in a diluted mixture $(1: 100)$ of donkey antirabbit IgG with donkey anti-goat or donkey anti-mouse IgG. After coverslipping, sections were imaged with a 10$40 \times$ or $60 \times$ oil-immersion objective on a confocal laser scanning microscope system (Bio-Rad Radiance 2100). Fluorescent markers, including fluorescein isothiocyanate (FITC) or rhodamine, were excited by a 488 or $543 \mathrm{~nm}$ laser beam and visualized via a HQ515/30 or E570LP emission filter. Some images were obtained by collapsing 8-16 consecutive $0.8 \mu \mathrm{m}$ thick optical sections into a single image.

\section{Image data analysis}

Terms and abbreviations of the histological structures of the cord were named according to the nomenclature described by Paxinos et al. [43]. The numbers of cells double-labeled for c-Fos and NeuN in the intermediolateral cell column (IML) of T3 spinal segments were counted manually. Counts only included the nuclear staining that aggregated in the lateral horn (see Results). For each experiment, the number of cells was averaged from counts of 5 sections, which were randomly selected from $~ 30$ transverse sections. Data from different experiments were grouped according to treatments. The difference in the numbers of cells between groups was evaluated using oneway analysis of variance followed by group comparisons using the least significant difference method. A $P$-value of $<0.05$ was considered significant. Values are presented as the mean \pm SEM.

\section{Results \\ Temperature-dependent SND genesis in thoracic spinal cord}

Spontaneous generation of cervical SND (cSND) and splanchnic SND (sSND) was examined when thoracic spinal cords were incubated at different bath temperatures ( $n$ $=21$ ). At $\leq 10^{\circ} \mathrm{C}$, both SNDs were quiescent (Fig. 1A). At $\geq 20^{\circ} \mathrm{C}$, SNDs were discernible and gradually augmented by increasing bath temperature. Oscillatory patterns of cSND and sSND were similar, showing power spectra with maximal peaks at $\sim 1-2 \mathrm{~Hz}$ (Fig. $1 \mathrm{~B}$ ). At $25^{\circ} \mathrm{C}$, spontaneous generation of SNDs persisted for $\geq 8 \mathrm{~h}$. We therefore considered $25^{\circ} \mathrm{C}$ as the optimal temperature for SND genesis in vitro. 
A

$10^{\circ} \mathrm{C}$

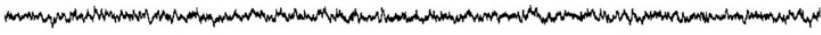

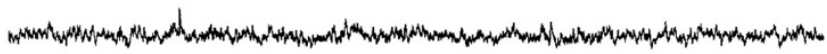

$15^{\circ} \mathrm{C}$

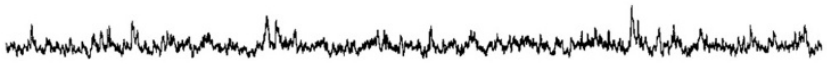
$20^{\circ} \mathrm{C}$

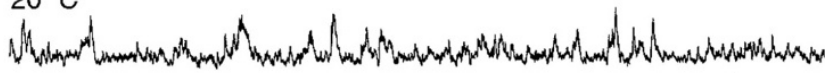

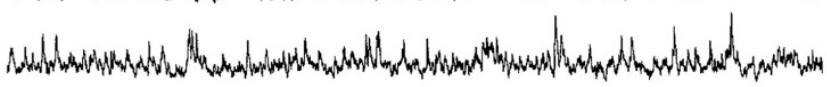

$25^{\circ} \mathrm{C}$

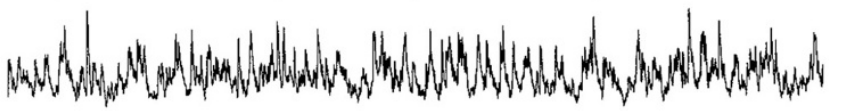
$25^{\circ} \mathrm{C}+24 \mathrm{mM} \mathrm{Mg}^{2+}$

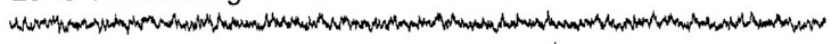

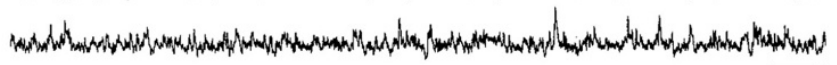
C

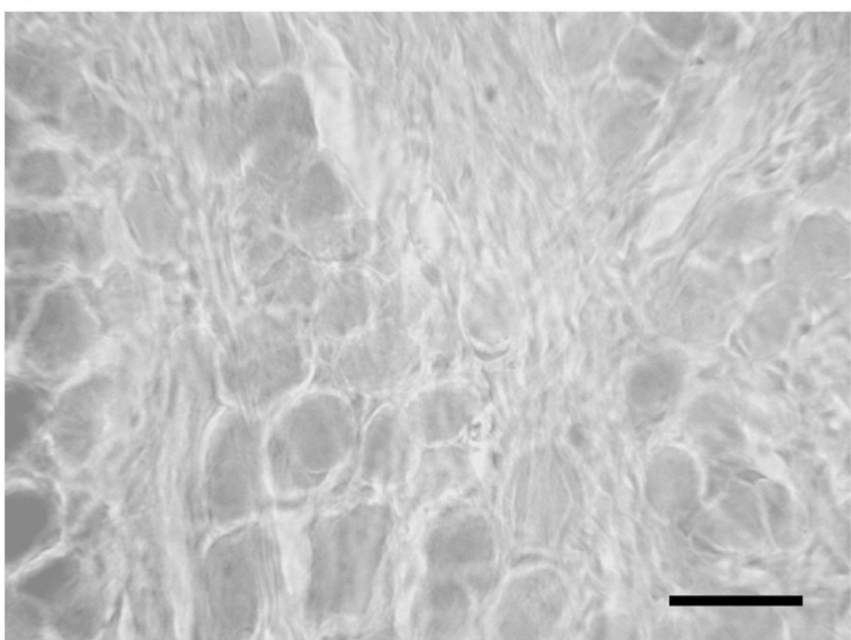

B

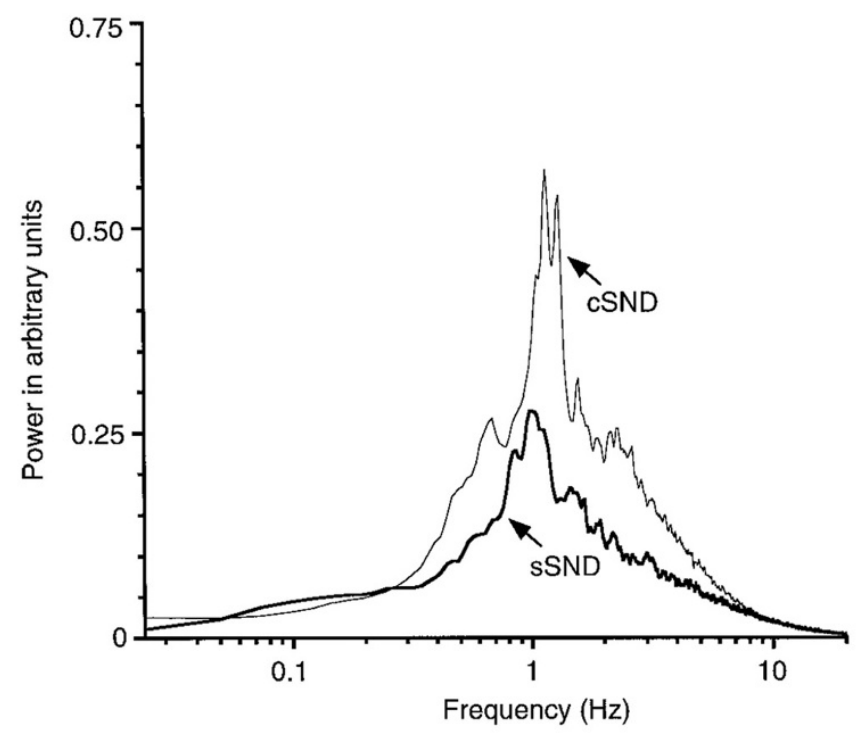

D

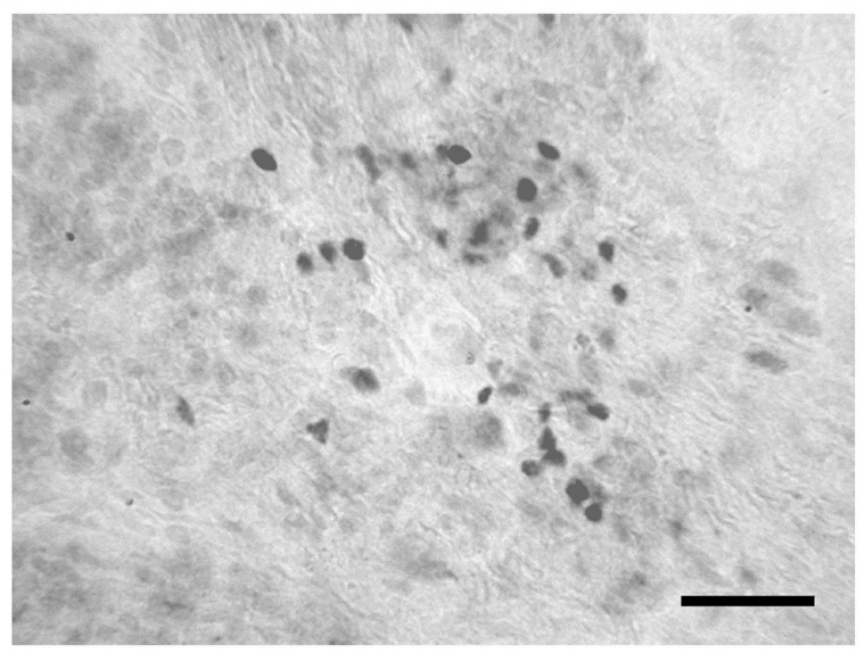

\section{Figure I}

Temperature-dependent features for in vitro nerve-cord preparations to generate sympathetic nerve discharge (SND). (A) Original traces of the SND envelope. Incubation temperature is indicated at the top of each panel. Upper and lower traces in each panel show envelopes of cervical SND (cSND) and splanchnic SND (sSND), respectively. SNDs were discernible at $\geq 20^{\circ} \mathrm{C}$. Adding $24 \mathrm{mM} \mathrm{Mg}^{2+}$ to the bath solution at $25^{\circ} \mathrm{C}$ reduced SNDs to the level at $10^{\circ} \mathrm{C}$. (B) Power spectra of cSND and sSND envelopes at $25^{\circ} \mathrm{C}$. Spectra were averaged from 21 experiments. Power spectra of both SNDs were similar, showing a peak at $\sim \mathrm{I} \mathrm{Hz}$. Photomicrographs in (C) and (D) show c-Fos protein expression in the dorsal root ganglion and celiac ganglion, respectively. The observation was obtained from a nerve-cord-ganglion preparation that incubated under optimal in vitro conditions for SND genesis $\left(25^{\circ} \mathrm{C}\right.$ normal aCSF, $\left.3 \mathrm{~h}\right)$. c-Fos-positive cells were absent in the dorsal root ganglion (C), but present in the celiac sympathetic ganglion (D). Scale bars $=30 \mu \mathrm{m}$ in (C, D). 


\section{Optimal incubation time for in vitro c-Fos expression} At the bath temperature optimal for SND genesis, the incubation time required for synthesis of detectable amounts of c-Fos was empirically evaluated in five preliminary experiments. Each experiment was constituted by three thoracic spinal cords incubated in normal aCSF for $1.5 \mathrm{~h}, 3 \mathrm{~h}$, and $6 \mathrm{~h}$. Figure 2 shows that oval or round nuclei with prominent c-Fos-immunoreactivity (IR) were concentrated in the IML of the cord incubated for $1.5 \mathrm{~h}$. More c-Fos-positive nuclei were observed in the IML of cords incubated for $3 \mathrm{~h}$. An extension of incubation time to $6 \mathrm{~h}$ resulted in a wider spread of c-Fos-positive nuclei in the medial ventrolateral regions. However, for cords with in vitro incubation times of $3 \mathrm{~h}$ and $6 \mathrm{~h}$, similar c-Fos staining was observed in the IML. We therefore chose $3 \mathrm{~h}$ as the optimal incubation time for in vitro c-Fos expression.
To verify that c-Fos expression is intrinsic to the cord and not secondary to primary afferent activation, we examined c-Fos expression in the dorsal root ganglion and the celiac ganglion $(n=5)$. Experiments were performed in preparations that received intact primary afferents from the dorsal root ganglia and had their splanchnic nerves innervated the celiac ganglion. These nerve-cord-ganglia preparations were incubated at $25^{\circ} \mathrm{C}$ for $3 \mathrm{~h}$. c-Fos-positive cells were absent in the dorsal root ganglia (Fig. 1C); however, they were present in the celiac ganglion (Fig. 1D).

\section{SND-correlated c-Fos expression in thoracic spinal cord in vitro}

c-Fos expression patterns in the cords incubated in bath temperatures favorable $\left(25^{\circ} \mathrm{C}\right)$ or unfavorable $\left(\leq 10^{\circ} \mathrm{C}\right)$ for SND genesis were compared in 7 experiments. Each experiment consisted of two cords incubated for $3 \mathrm{~h}$ at $\leq$
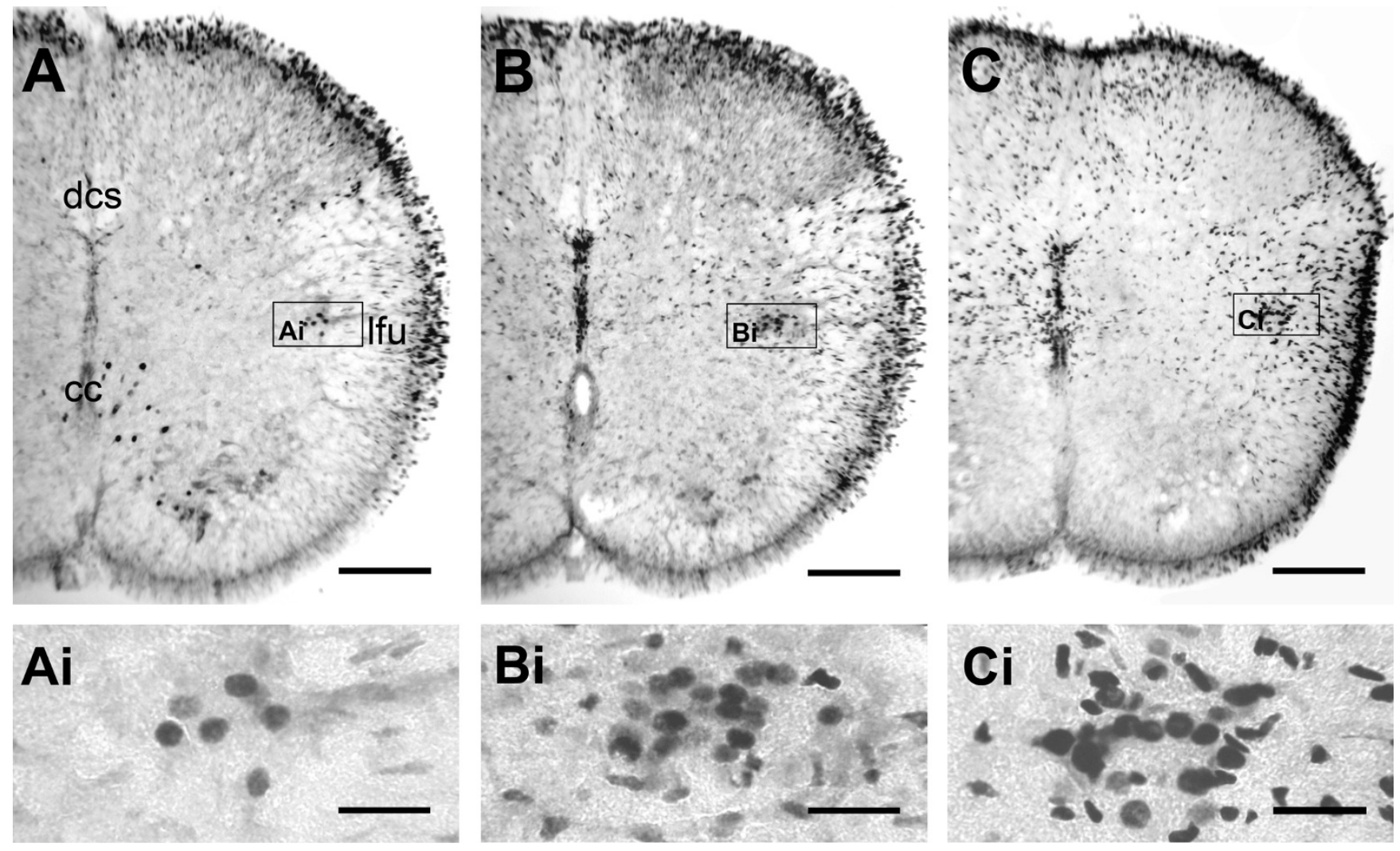

\section{Figure 2}

Time course of c-Fos expression in the cords incubated in $25^{\circ} \mathrm{C}$ normal aCSF. Photomicrographs show transverse sections of T3 from three preparations with different incubation time in hours: I.5 (A), 3 (B), and 6 (C). After I.5 h incubation, limited cells with intense c-Fos immunoreactivity $(I R)$ were found in the IML ( $\mathrm{Ai})$. As the incubation time was prolonged to $3 \mathrm{~h}$, c-Fos-positive cells in the IML increased (Bi), and were comparably abundant in the cord after the $6 \mathrm{~h}$ incubation (Ci). Note the presence of c-Fos-positive cells in the ventral horn and around the $c c$ in $(A)$ and the absence of these cells in (B, $C$ ). Also note the time-dependent spread of cell distribution to medial ventrolateral regions of the cord. Histological abbreviations in this and following figures: cc, central canal; dcs, dorsal corticospinal tract; IML, intermediolateral cell column; Ifu, lateral funiculus. Scale bars $=150 \mu \mathrm{m}$ in $(\mathrm{A}-\mathrm{C})$ and $30 \mu \mathrm{m}$ in $(\mathrm{Ai}-\mathrm{Ci})$. Detailed distributions of c-Fos-positive cells in the cord are shown in following figures. 
$10^{\circ} \mathrm{C}$ and $25^{\circ} \mathrm{C}$, respectively. c-Fos-positive nuclei were rarely observed in cords incubated at $\leq 10^{\circ} \mathrm{C}$ (Fig. 3A); only a few were found in the IML (Fig. 3Aii) and the area around the central canal (cc; Fig. 3Aiv). The c-Fos-positive cells in the area around the cc were also observed in cords incubated at $25^{\circ} \mathrm{C}$ for $1.5 \mathrm{~h}$ (Fig. $2 \mathrm{~A}$ ). However, they did not persist in cords incubated at $25^{\circ} \mathrm{C}$ for $3-6 \mathrm{~h}$ (Figs. 2B, 2C, and 3Biv).

In contrast, abundant c-Fos-positive cells were observed in cords incubated at $25^{\circ} \mathrm{C}$. The cells were concentrated in lamina $\mathrm{X}$ and the IML. Some were scattered in the dorsal laminae with a denser distribution in the superficial layers (Fig. 3B). c-Fos-positive cells also appeared in the white matter, showing a sparse distribution in the lateral funiculus (lfu) and a dense accumulation around its outer rim (Figs. 3Bii). The distribution patterns were similar across different spinal segments.

For comparisons, in vivo c-Fos expression patterns under physiological conditions were investigated in the rats that were deeply anesthetized with halothane for $\sim 2 \mathrm{~min}$, promptly decerebrated, and transcardially perfused with cold oxygenated aCSF followed by $4 \%$ paraformaldehyde $(n=7)$. Without in vitro incubation, the expression of cFos under physiological conditions was found in the IML, the dorsal laminae near the dorsal corticospinal tract (dcs), the ventral horn, and areas around the cc (Fig. 4). In vivo c-Fos expression in the ventral horn and the cc areas was not observed in cords with in vitro incubations. In contrast, in vitro c-Fos expression in lamina $\mathrm{X}$ and the white matter was not observed in cords in vivo. In the IML and the dorsal laminae, however, the c-Fos expression under in vivo and in vitro conditions was largely similar.

\section{c-Fos-positive cell identities}

The colocalization of c-Fos-IR with IR of glial fibrillary acidic protein (GFAP; $n=4$ ) or IR of neuron-specific nuclear protein (NeuN; $n=6$ ) was examined to verify whether c-Fos-positive cells were neuroglial cells or neurons. Fibrillary processes with intense GFAP-IR were found in all regions of the cord and more extensively distributed in the white matter than the gray matter. Figure 5 shows the confocal images of the lateral regions of T6 spinal segment double-labeled for c-Fos and GFAP. The large round c-Fos-positive nuclei in the IML were not closely surrounded by GFAP-IR (Fig. 5A). In contrast, the small slender c-Fos-positive nuclei in the lfu were in close proximity to GFAP-IR (Fig. 5B). Figure 6 shows the confocal images of T3 and T9 spinal segments double-labeled for cFos and NeuN. NeuN-positive nuclei were mainly distributed in the gray matter. Some were scattered in the lfu (Fig. 6Cii). Nuclei with positive c-Fos-IR and negative NeuN labeling were found in the lfu, the outer rim of the white matter, and lamina $\mathrm{X}$. In contrast, nuclei double- labeled for c-Fos- and NeuN-IR were concentrated in the IML (Fig. 6Ai), and scattered in the dorsal laminae with a denser distribution in the superficial layers (Fig. 6Bi and 6Ci).

Because SPNs are one of the cholinergic neurons in the spinal cord, the colocalization of c-Fos-IR with IR of choline acetyltransferase (ChAT) was used as a criterion to identify the histological distribution of active SPNs $(n=$ 6). ChAT-IR was mainly observed in the ventral horn, lamina $X$, intermediomedial region of the gray matter, the IML, and scarcely found in the dorsal laminae (Fig. 7). No c-Fos-positive nuclei were observed in the ventral horn. The c-Fos positive cells distributed in the dorsal lamina $\mathrm{X}$ that located just ventral to the dorsal corticospinal tract (dcs) were ChAT-negative (open arrowheads, Fig. 7Aii). Therefore, c-Fos-positive nuclei in close proximity to ChAT-IR were only present in the IML.

\section{Effects of TTX, MECA, or KYN on c-Fos expression patterns}

Whether intact synaptic transmission was required for cFos expression were examined in cords when SND genesis was interrupted by blocking action potential generation using $0.5 \mu \mathrm{M}$ TTX or by attenuating endogenous nicotinic receptor activities using $20 \mu \mathrm{M}$ MECA ( $n=5$ in each test). For comparisons, we also examined c-Fos expression patterns in cords incubated in aCSF containing $800 \mu \mathrm{M} \mathrm{KYN}$ to block ionotropic glutamate receptors $(n=8)$, which did not suppress SND genesis [37]. Figures 8 and 9 illustrate drug-induced change in histological and electrophysiological responses, respectively. SSND is abolished or attenuated by TTX or MECA applications, but not apparently affected by KYN applications (Fig. 9A). In cords incubated in aCSF containing TTX or MECA (Fig. $8 \mathrm{Bi}$ and $8 \mathrm{Ci}$ ), cFos-positive neurons were rarely observed in the dorsal laminae; however, they persisted in the IML (Fig. 8Bii and $8 \mathrm{Cii}$ ). In contrast to cords incubated in aCSF containing $800 \mu \mathrm{M} \mathrm{KYN}, \mathrm{c}$-Fos-positive neurons were observed in the dorsal laminae and the IML (Fig. 8D). Because TTX- or MECA-induced change of c-Fos expression in dorsal laminae was obvious and montage of high-magnification fluorescent photographs were difficult using our image setup, further quantification of c-Fos-positive neurons in dorsal laminae was not pursued. Only the numbers of cFos-positive neurons in the IML of T3 spinal cord segments were counted (Fig. 9). Abundance of c-Fos-positive neurons in the IML was not different between cords incubated in normal aCSF and in aCSF containing TTX or $\mathrm{KYN}$. However, c-Fos expression in the IML was significantly reduced in cords incubated in aCSF containing MECA (control vs. MECA: $8.2 \pm 1.1$ vs. $3.8 \pm 0.5 ; P<0.01$ ). 

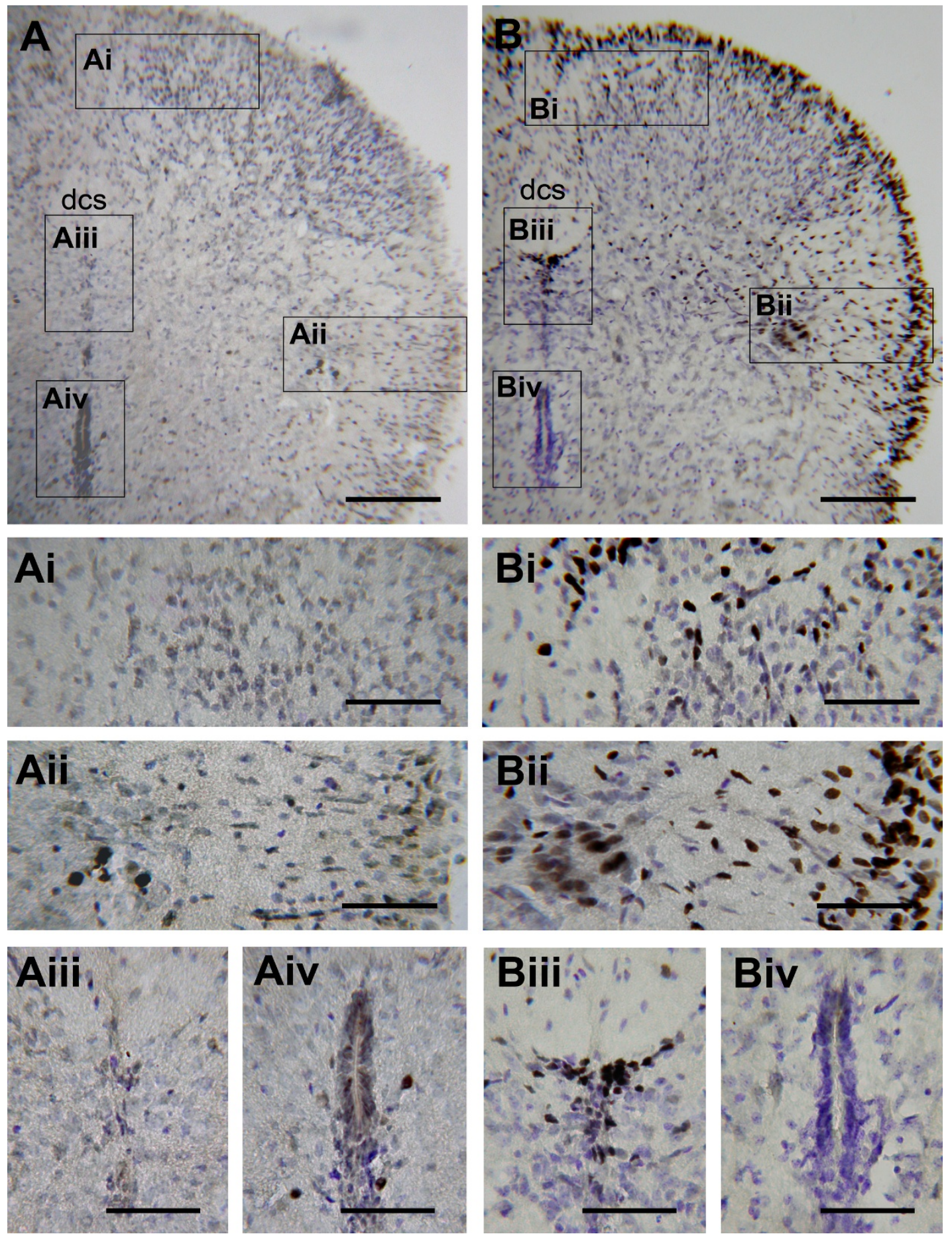

Figure 3

Temperature-dependent in vitro c-Fos expression in the cord. Tissue sections were counterstained with cresyl violet. Photomicrographs show the dorsal quadrant of transverse sections of T3 from the cord with $3 \mathrm{~h}$ incubation in $\leq 10^{\circ} \mathrm{C}(\mathrm{A})$ or $25^{\circ} \mathrm{C}$ (B) normal aCSF. In the cord incubated at $\leq 10^{\circ} \mathrm{C}$, only a few c-Fos-positive cells were found in the IML (Aii) and around the cc (Aiv). In the cord incubated at $25^{\circ} \mathrm{C}$, abundant c-Fos-positive cells concentrated in the IML (Bii) and the lamina $\mathrm{X}$ (Biii); some were scattered throughout the dorsal laminae $(\mathrm{Bi})$ or the lfu $(\mathrm{Bii})$, and accumulated in the outer rim of the white matter $(\mathrm{B}, \mathrm{Bii})$. A few c-Fos positive cells scattered around the cc were observed in the cord incubated at $\leq 10^{\circ} \mathrm{C}$ (Aiv), which were absent when the cord was incubated at $25^{\circ} \mathrm{C}$ (Biv). Scale bars $=150 \mu \mathrm{m}$ in (A, B) and $60 \mu \mathrm{m}$ in (Ai-iv, Bi-iv). 

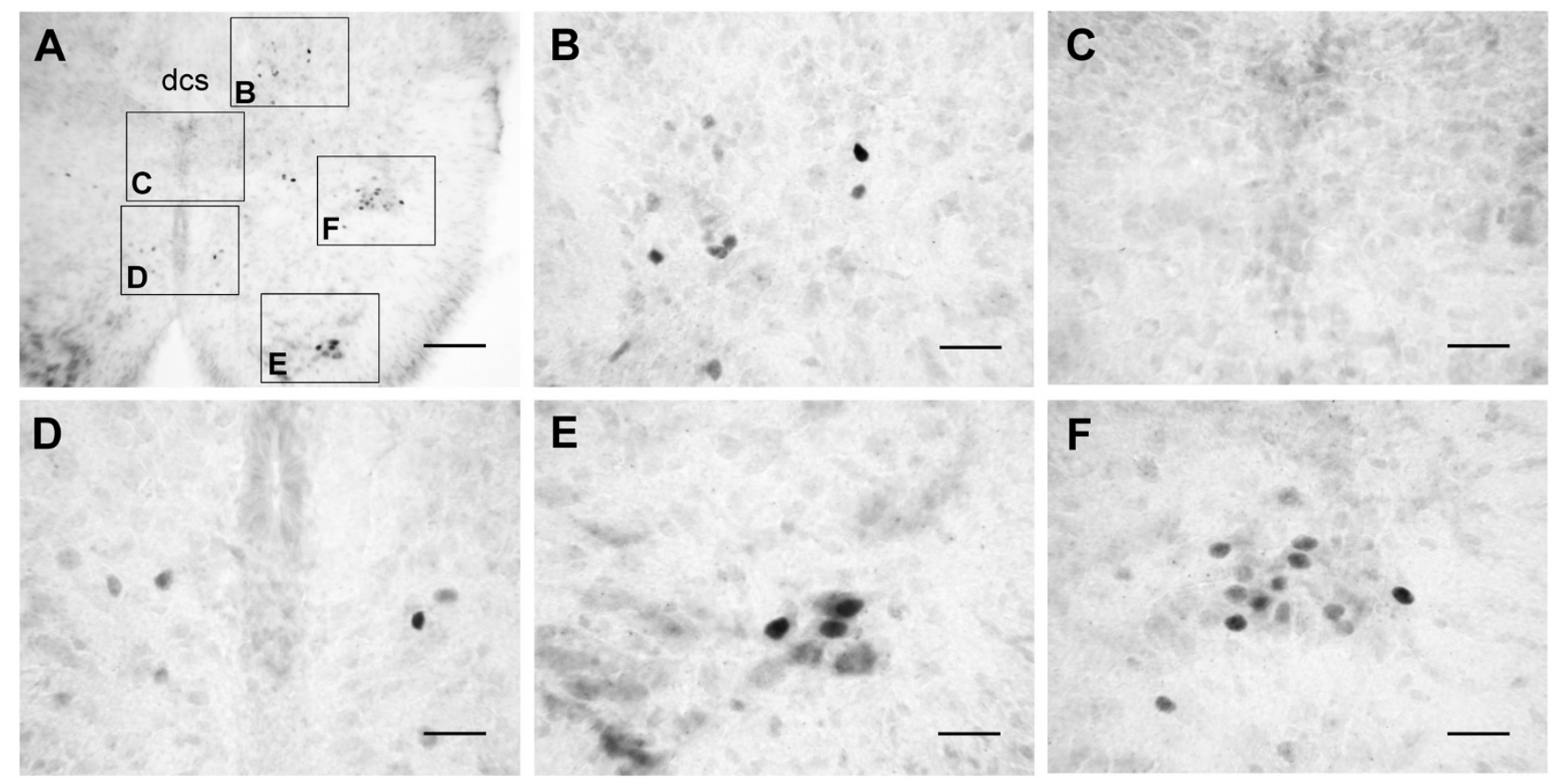

Figure 4

In vivo c-Fos expression in the cord. Basal levels of c-Fos expression under normal physiological conditions were promptly preserved by a transcardial perfusion of fixative. (A) Photomicrograph of a transverse section of the T3 spinal cord segment. Insets in (A) are magnified as indicated. c-Fos-positive nuclei were distributed in the dorsal laminae near the dcs (B), around the Cc (D), in the ventral horn (E), and in the IML (F). No c-Fos-positive cells were found in lamina $X(C)$, the Ifu, or the outer rim of the white matter (A). Scale bars $=100 \mu \mathrm{m}$ in $(A)$ and $25 \mu \mathrm{m}$ in (B-F).

\section{Discussion}

We have demonstrated that c-Fos-positive neurons were found in the dorsal laminae and the IML when the thoracic spinal cord was incubated under optimal conditions for SND genesis in vitro. The IML neurons were SPNs because they were also ChAT-positive. In cords treated with TTX or MECA to reduce SND genesis, c-Fos expression in the dorsal laminae diminished; however, c-Fos expression in some SPNs persisted. These observations suggest that the excitatory signals originated from action potential-dependent or nicotinic receptor-mediated synaptic transmission are required for c-Fos expression in the dorsal laminae, but not essential for c-Fos expression in some SPNs. Therefore, those SPNs that are capable of cFos expression in the presence of TTX or MECA may play key roles in SND genesis.

\section{c-Fos expression encodes the neural substrates related to SND genesis}

The expression of c-Fos and the generation of sympathetic activity in the cord have similar temperature dependence. This temperature effect might indicate only a casual correlation. Thermal effects on biochemical reactions are generic in a biological system. Temperature has profound influences on molecular interactions that govern neurotransmitter release and kinetics of ion channels. Therefore, the c-Fos expression in cords incubated in higher ambient bath temperature could be argued as nonspecific. However, several lines of evidence support the view that the temperature-dependent expression of c-Fos is related to SND genesis. First, in cords kept at the optimal temperature for SND genesis and incubated for $3 \mathrm{~h}$ to allow in vitro c-Fos expression, c-Fos-positive cells were found in the IML. This histological observation is consistent with the electrophysiological data that SPNs are active under the in vitro conditions. Second, anatomical and electrophysiological studies have shown that sympathetic-correlated neurons are distributed in the medial dorsal parts of thoracic spinal cord [15-17,21]. Consistent with previous findings, we found that the c-Fos-positive neurons are distributed in the dorsal laminae. The similarity in anatomical distribution indicates that some dorsal laminae neurons may participate in SND genesis in vitro. Third, applications of MECA suppressed SND genesis in cords [36] and reduced c-Fos expression in the dorsal laminae, an effect that was not replicated by applications of KYN. Therefore, c-Fos expression in the dorsal laminae reflects a functional operation of the neural elements underlying 

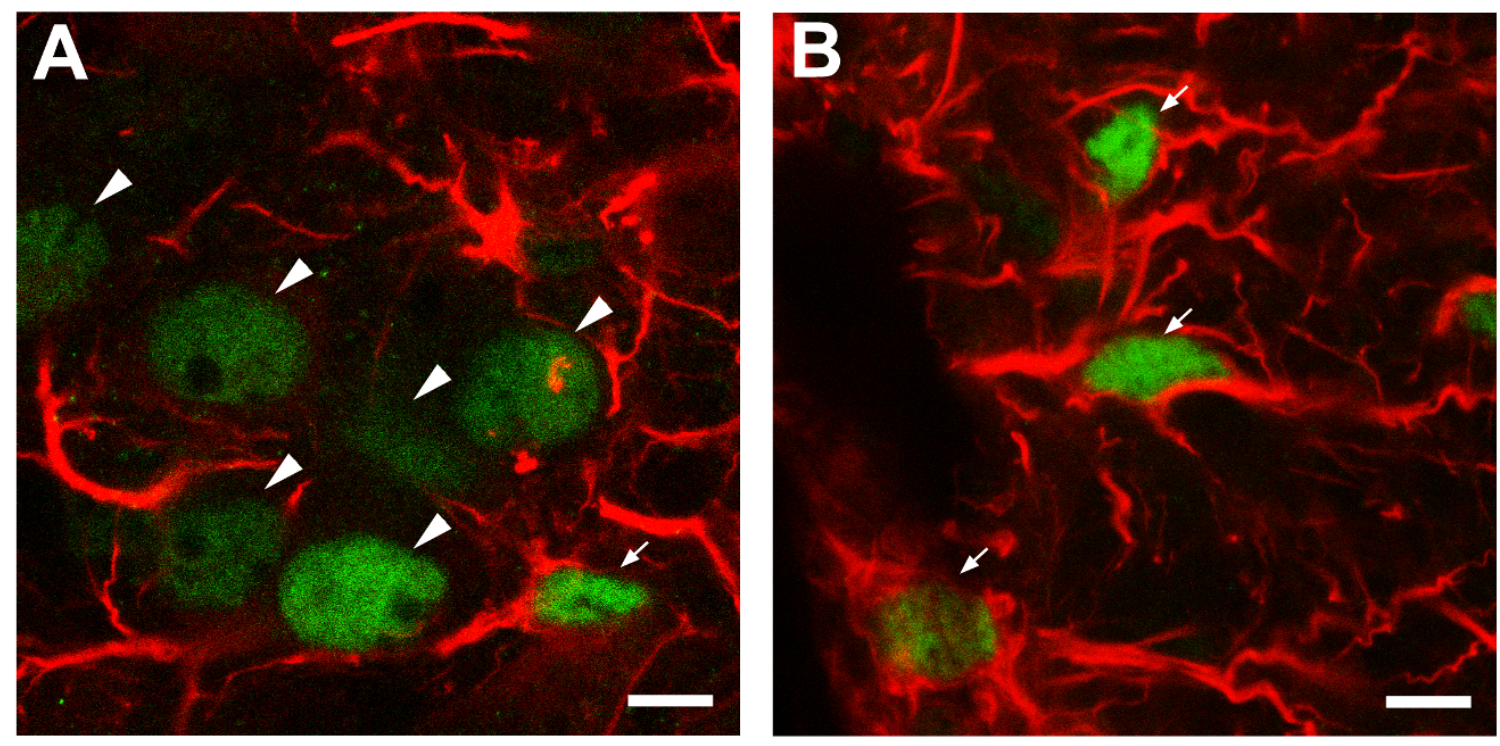

\section{Figure 5}

Confocal images of a transverse section of T6 spinal cord segment, showing c-Fos (FITC) and GFAP (rhodamine) labeling in the IML $(A)$ and the Ifu $(B)$. Arrowheads: neuronal nuclei, indicating isolated nuclear c-Fos-IR not surrounded by fibrillary GFAP-IR. Arrows: neuroglial nuclei, indicating nuclear c-Fos-IR in close proximity to fibrillary GFAP-IR. (A) Concentrated c-Fos-positive neurons with large round nuclei (arrowheads) in the IML. The neuroglial cells have small slender nuclei (arrows; one at the upper right is only faintly labeled for c-Fos-IR). (B) c-Fos-positive neuroglial cells in the Ifu. Here, nuclear c-Fos-IR is intimately embedded in GFAP-IR (arrows). Scale bars $=10 \mu \mathrm{m}$ in (A, B).
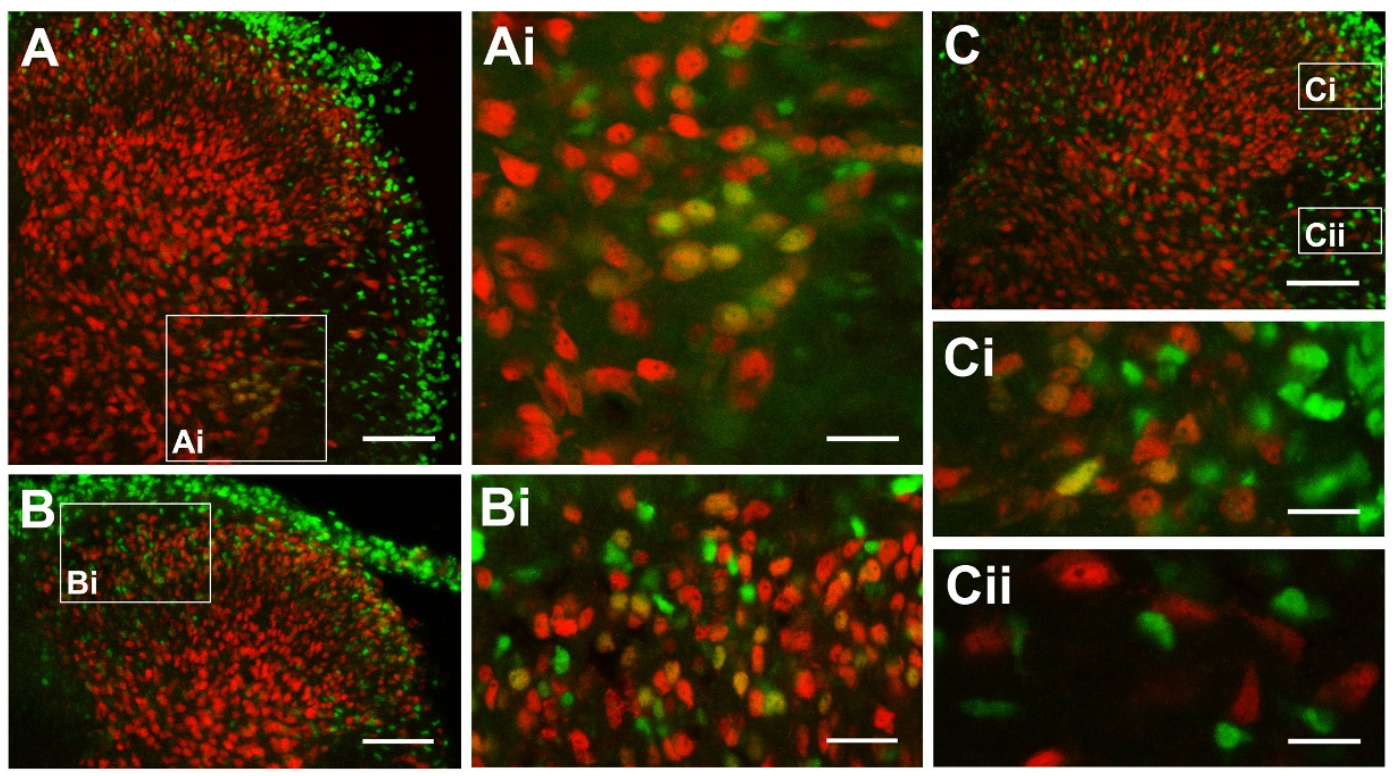

\section{Figure 6}

Distribution of c-Fos-positive neurons in the dorsal laminae and the IML. Photomicrographs show transverse sections of T3 (A, B) and T9 (C) spinal cord segments. Nuclei with double labeling for c-Fos-IR (FITC) and NeuN-IR (rhodamine) were found in the IML $(\mathrm{A}, \mathrm{Ai})$, the internal dorsal laminae $(\mathrm{B}, \mathrm{Bi})$ and the external dorsal laminae $(\mathrm{C}, \mathrm{Ci})$. All c-Fos-positive nuclei in the Ifu and the outer rim of the white matter were NeuN-negative (Cii). Scale bars $=100 \mu \mathrm{m}$ in (A-C), $35 \mu \mathrm{m}$ in (Ai, $\mathrm{Bi})$, and $20 \mu \mathrm{m}$ in (Ci-ii). 

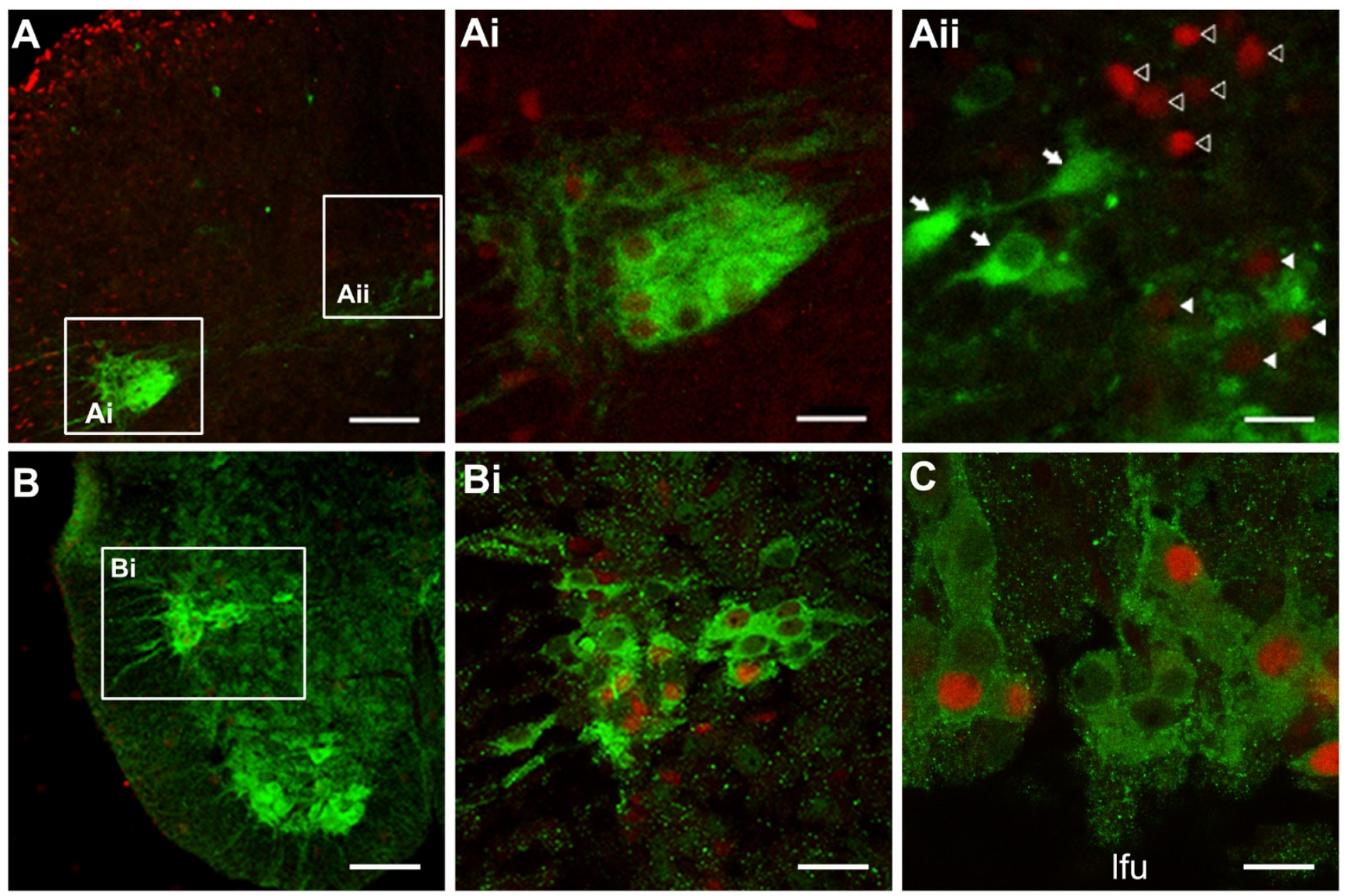

\section{Figure 7}

Colocalization of c-Fos-IR (rhodamine) and ChAT-IR (FITC) to demonstrate that c-Fos-positive neurons in the IML are cholinergic sympathetic preganglionic neurons (SPNs). Insets in (A, B) are magnified as indicated. (A) Low magnification photomicrograph of the dorsal quadrant of a transverse section of T3 spinal cord segment. A triangular cluster of IML cells showed intense ChAT-IR that embraced nuclei labeled with c-Fos-IR (Ai). Distribution of ChAT-positive cells extended dorsomedially toward the intermediate zone of lamina X (Aii), where localizations of ChAT-IR and c-Fos-IR were separate. In (Aii), open arrowheads on Top indicate c-Fos-positive ChAT-negative cells in the dorsal lamina X; filled arrowheads at Bottom indicate nuclei with mild c-Fos-IR surrounded by diffusive ChAT-IR in the ventral lamina X. Arrows indicate ChATpositive c-Fos-negative cells in the intermediate zone. (B) Low magnification photomicrograph of the ventral quadrant of a transverse section of T5 spinal cord segment. ChAT-IR was present in the IML and the ventral horn; only in the IML, ChAT-IR was colocalized with c-Fos-IR (Bi). (C) High magnification photomicrograph of a horizontal section of T7-T8 spinal cord segments, showing c-Fos-positive nuclei in close proximity to cytoplasmic-like ChAT-IR in the IML. Scale bars $=100 \mu \mathrm{m}$ in $(A, B)$, $25 \mu \mathrm{m}$ in (Ai-ii), and $20 \mu \mathrm{m}$ in $(\mathrm{Bi}, \mathrm{C})$.

SND genesis. The activity of dorsal laminae neurons is likely to be driven, either directly or indirectly, by nicotinic receptor activation.

\section{Implications of glial activation for in vitro SND genesis}

One intriguing observation in this study was that with in vitro incubations, c-Fos-positive and NeuN-negative gliallike cells were abundant in lamina $\mathrm{X}$, the dorsal laminae, and the lfu. c-Fos expression in these areas was largely absent under in vivo conditions (Fig. 4). The lack of blood circulation under in vitro conditions inevitably led to interstitial accumulations of metabolites, which might result in glial activation as revealed by c-Fos expression. Glial activation is required to maintain a homeostatic neuronal environment [44-46]. Therefore, the distribution pattern of c-Fos-positive neuroglia implies a spontaneous neural activity in the regions. Whether the interplay between the active neural elements and the activated neuroglia plays a role in SND genesis awaits for further studies.

\section{Spontaneously active SPNs in the IML}

Only the cholinergic neurons aggregated in the IML expressed c-Fos. All the other cholinergic neurons were c- 

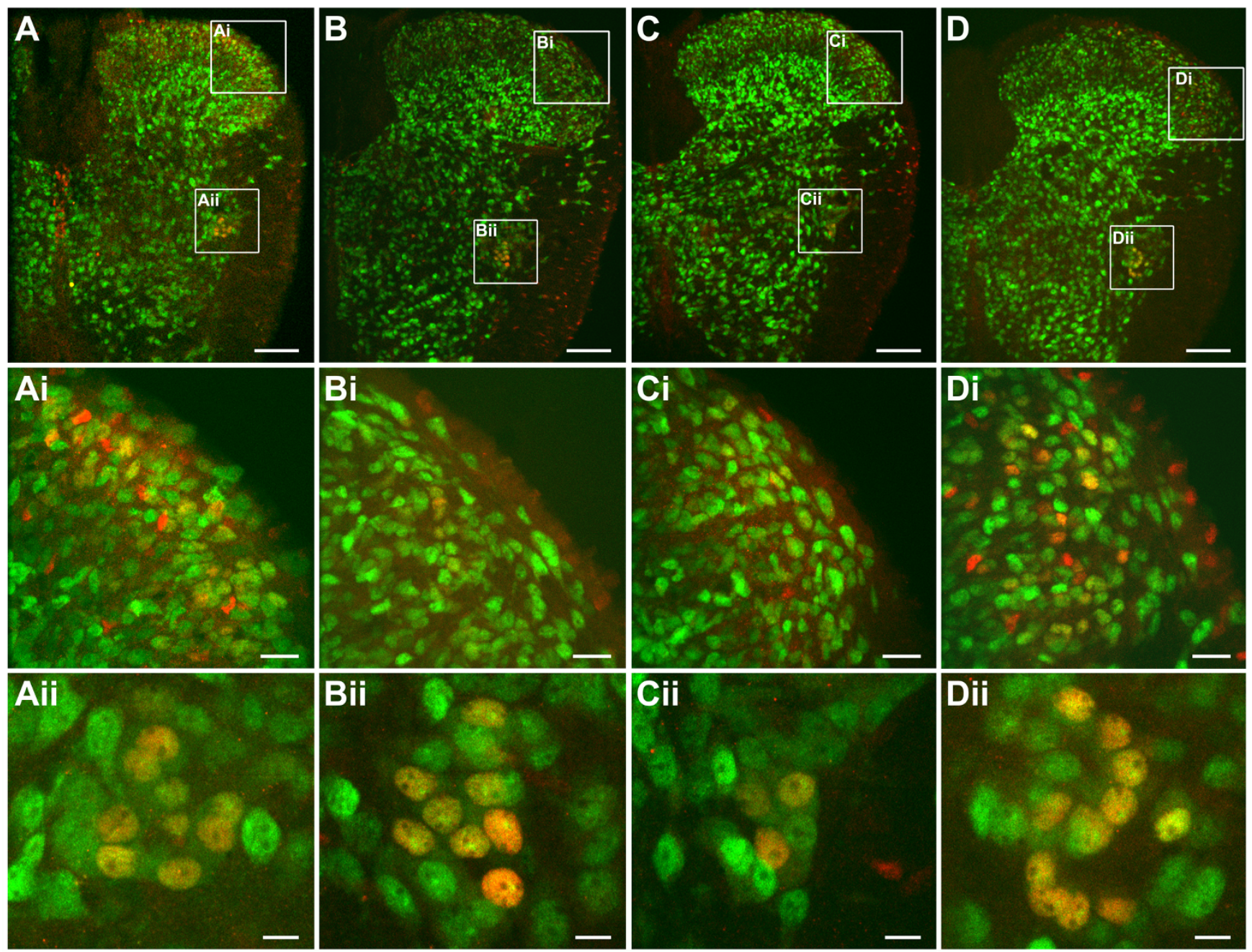

Figure 8

Distribution of c-Fos-positive neurons in the cords incubated in normal aCSF (A) or aCSF containing $0.5 \mu M$ TTX (B), $20 \mu$ M MECA (C), or $800 \mu M$ KYN (D). c-Fos-positive neurons are revealed by double labeling of NeuN-IR (FITC) and c-Fos-IR (rhodamine). Compared with the control (Ai), c-Fos expression in the dorsal laminae neurons was apparently reduced by TTX $(\mathrm{Bi})$ or MECA $(\mathrm{Ci})$ but not by KYN treatment ( $\mathrm{Di})$. In the IML, the abundance of c-Fos-positive neurons was diminished only by MECA (Cii), but not by TTX (Bii) or KYN treatment (Dii). Scale bars = I00 $\mu \mathrm{m}$ in $(\mathrm{A}-\mathrm{D}), 20 \mu \mathrm{m}$ in $(\mathrm{Ai}-$ $\mathrm{Di}$ ), and $10 \mu \mathrm{m}$ in (Aii-Dii).

Fos-negative. In addition to the IML, SPNs are distributed in the intermediomedial regions and the central autonomic areas. The lack of c-Fos expression in these regions suggests that these SPNs do not contribute to SND genesis in vitro. Therefore, the SPNs of the IML are the only active cholinergic neurons during SND genesis in vitro.

Surprisingly, c-Fos expression in the SPNs of the IML was largely not altered after blocking action potential generation by TTX applications, but it was significantly reduced after blocking endogenous nicotinic receptor activities by MECA applications. It has been reported that nicotine- activated c-Fos expression in PC12 cells is TTX-resistant but MECA-sensitive [47]. TTX-resistant c-Fos expression was also observed in chemosensitive cells in the superficial ventral medulla of rats [48]. In our studies, although the suppression of SND genesis induced by TTX or MECA applications was similar, its underlying mechanisms were different. TTX applications block action potential-dependent neurotransmission and leave many TTX-resistant channel activities intact. In contrast, MECA applications block nicotinic receptor-mediated neurotransmission and let the neurotransmissions mediated by other receptor types function normally. SPNs are inhibited by GABAergic 


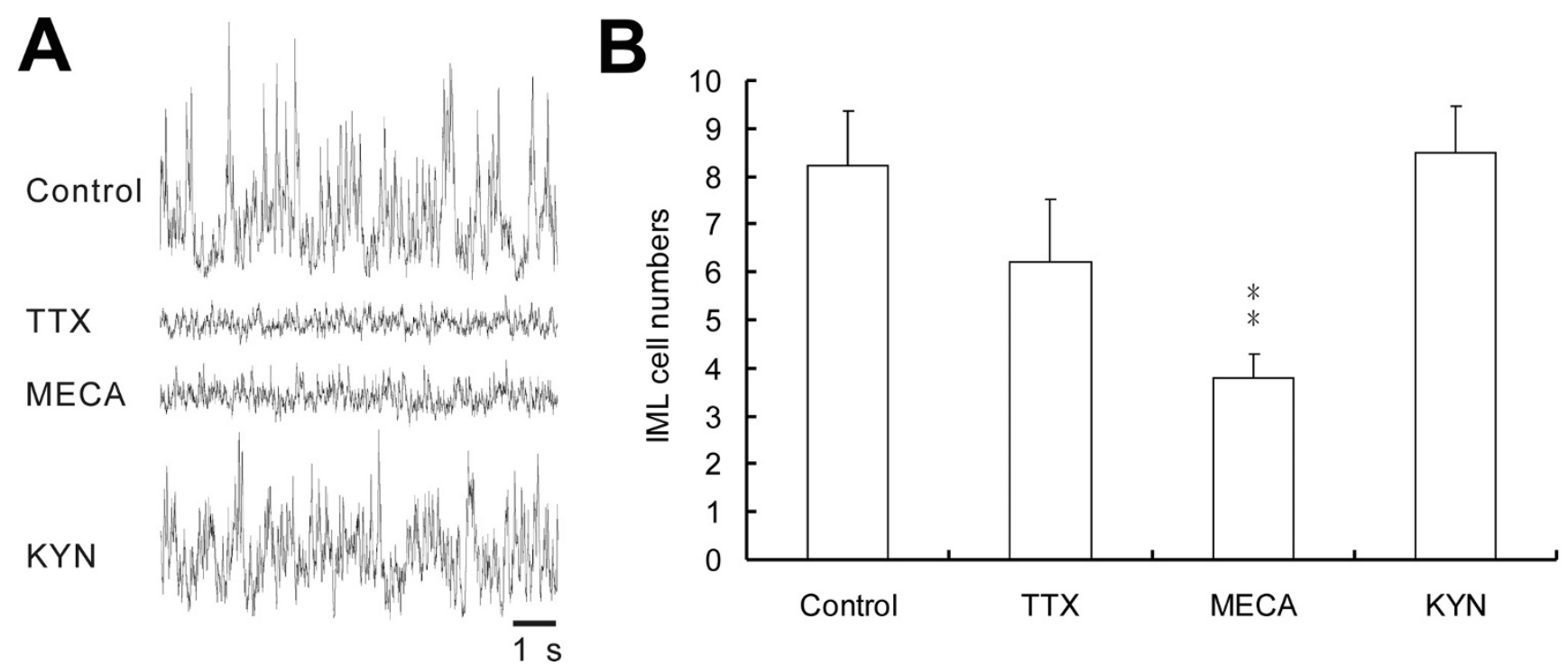

Figure 9

Drug-induced changes in SND genesis and in the numbers of c-Fos-positive IML neurons. The spinal cords were incubated in normal aCSF (control) or aCSF containing $0.5 \mu \mathrm{M}$ TTX, $20 \mu \mathrm{M}$ MECA, or $800 \mu \mathrm{M}$ KYN. (A) Original traces of the sSND envelope. sSND was abolished or reduced in cords incubated in aCSF containing TTX or MECA, but not apparently affected by application of KYN. (B) Numbers of c-Fos-positive neurons in the IML. The numbers were obtained from averaging counts of IML cells double labeled for c-Fos-IR and NeuN-IR in transverse sections of T3 spinal cord segments (30- $\mu \mathrm{m}$-thickness). Compared with the control $(8.2 \pm \mathrm{I} . \mathrm{I} ; n=6)$, the number of c-Fos-positive neurons was significantly reduced by application of MECA $(3.8 \pm 0.5 ; n=5 ; P<0.0 \mathrm{I})$, but not by application of TTX $(6.2 \pm 1.3 ; n=5)$ or KYN $(8.5 \pm 0.6 ; n=8)$.

and glycinergic neurotransmission [23,49-51]. These inhibitory activities would not be directly affected by MECA, but could be abolished by TTX. It is likely that, impinged upon SPNs, the presence of inhibitory activities during MECA applications explains why c-Fos expression is reduced by MECA but not by TTX.

Moreover, MECA is an open-channel blocker, which can only be effective when nicotinic receptors are activated [52]. Thus, MECA-induced suppression of c-Fos expression in the IML is partly because these SPNs are continuously excited, be it directly or indirectly, by nicotinic receptor activation [36]. The source of cholinergic activity for nicotinic receptor activation was not determined in this study. However, colocalization of c-Fos-IR with ChAT-IR is only found in the IML (Fig. 7), suggesting that IML SPNs are the only active cholinergic neurons in the cord. Therefore, under our experimental conditions, initiation of SND may originate from a few spontaneously active SPNs in the IML, which are capable of TTX- or MECA-resistant c-Fos expression. This view is consistent with earlier observations from other laboratories that some SPNs are spontaneously active $[7,8,53]$.

\section{Intraspinal sources for induction of c-Fos expression in dorsal laminae}

Sympathetic-correlated neurons are mainly located in the dorsal laminae I-V $[21,22,54,55]$, lamina VII [19], and in the vicinity of IML $[56,57]$. Under normal physiological conditions, supraspinal commands exert inhibitory influences to suppress sympathetic-correlated neurons in the dorsal laminae, which may normally function as relays for spinal sympathetic reflex [58-61].

We have found that, in addition to the presence of active SPNs in the IML, active neurons double-labeled for c-Fos and NeuN are also present in the dorsal laminae (Fig. 6). This finding is similar to the observations in adult rats that c-Fos expression after spinal cord transection is found in laminae I, IIo (outer substantia gelatinosa), Vre (lateral reticulated division), VII (lamina intermedia), $\mathrm{X}$, and the IML [62]. Induction of c-Fos expression in dorsal laminae neurons could not be attributed to the excitatory signals from extraspinal sources. First, the brain stem and the cervical cord were removed in this nerve-cord preparation. Second, somatovisceral inputs from the primary afferents were quiescent under in vitro conditions, as indicated by the absence of c-Fos-positive cells in the dorsal root ganglion. Therefore, an intraspinal source is responsible for the induction of c-Fos expression in the dorsal laminae. 
A few SPNs in vertebrates have intraspinal axon collaterals $[9,63,64]$. In adult rats, some SPNs with somata located outside the IML have axons branched within the spinal gray [63]. The axon collateral terminals are exclusively presynaptic to small caliber dendrites and form only asymmetric specializations, suggesting a conveyance of excitatory signals $[63,64]$. In neonatal rats, histological examinations of 45 SPNs reveal that 2 SPNs have axonal branches in lamina VII or the ventral horn [9]. Through their axon collaterals, we are tempted to speculate that some SPNs may play a stimulatory role in activation of other neural groups in the cord, including the sympathetic-correlated neurons in the dorsal laminae. Our observation that c-Fos expression in the dorsal laminae neurons was almost abolished by incubating the cords in aCSF containing TTX or MECA lends limited support to this speculation.

\section{Abbreviations}

cc: central canal; ChAT: choline acetyltransferase; DAB: diaminobenzidine; dcs: dorsal corticospinal tract; FITC: fluorescein isothiocyanate; GFAP: glial fibrillary acidic protein; IML: intermediolateral cell column; IR: immunoreactivity; KYN: kynurenate; lfu: lateral funiculus; MECA: mecamylamine; NeuN: neuron-specific nuclear protein; SND: sympathetic nerve discharge; SPN: sympathetic preganglionic neuron; TTX: tetrodotoxin.

\section{Competing interests}

The authors declare that they have no competing interests.

\section{Authors' contributions}

CKS and CMH participated in experimental design, data interpretation, and manuscript preparation. HHK and YCW conducted pharmacological and immunohistochemical experiments and data analysis. CYC was involved in overall research planning and assisted in manuscript preparation. All authors read and approved the final manuscript.

\section{Acknowledgements}

We are grateful to Drs. Jane B. Minson and Ida J. Llewellyn-Smith for research inspiration, Ms. Shin Lin, Yi-Wen Cheng, and Mr. Kuan-You Chou for excellent technical assistance. Hsiao-Hui Kuo was supported by funding from Taipei Veterans General Hospital (V95CI-034). This work was supported by grants from the National Science Council of the Republic of China (NSC 93-2320-B-00I-024) and in part by the C.Y. Foundation for Advancement of Education, Sciences, and Medicine.

\section{References}

I. Barman SM, Orer HS, Gebber GL: The role of the medullary lateral tegmental field in the generation and baroreceptor reflex control of sympathetic nerve discharge in the cat. Ann N Y Acad Sci 200I, 940:270-85.

2. Lipski J, Lin J, Teo MY, van Wyk M: The network vs. pacemaker theory of the activity of RVL presympathetic neurons - a comparison with another putative pacemaker system. Auton Neurosci 2002, 98:85-89.
3. Dampney RA, Horiuchi J, Tagawa T, Fontes MA, Potts PD, Polson JW: Medullary and supramedullary mechanisms regulating sympathetic vasomotor tone. Acta Physiol Scand 2003, I 77(3):209-I8.

4. Guyenet PG: The sympathetic control of blood pressure. Nat Rev Neurosci 2006, 7(5):335-46.

5. Su C-K, Phoon S-L, Yen C-T: Identification of active thoracic spinal segments responsible for tonic and bursting sympathetic discharge in neonatal rats. Brain Res 2003, 966:288-99.

6. McKenna KE, Schramm LP: Sympathetic preganglionic neurons in the isolated spinal cord of the neonatal rat. Brain Res 1983, 269:201-10.

7. Spanswick D, Logan SD: Spontaneous rhythmic activity in the intermediolateral cell nucleus of the neonate rat thoracolumbar spinal cord in vitro. Neuroscience 1990, 39:395-403.

8. Shen E, Wu SY, Dun NJ: Spontaneous and transmitter-induced rhythmic activity in neonatal rat sympathetic preganglionic neurons in vitro. J Neurophysiol 1994, 7 I(3): I I 97-205.

9. Su CK, Cheng YW, Lin S: Biophysical and histological determinants underlying natural firing behaviors of splanchnic sympathetic preganglionic neurons in neonatal rats. Neuroscience 2007, I 50:926-37.

10. Alexander RS: Tonic and reflex functions of medullary sympathetic cardiovascular centers. I Neurophysiol 1946, 9:205- 17.

II. Taylor RF, Schramm LP: Differential effects of spinal transection on sympathetic nerve activities in rats. Am J Physiol 1987, 253(22):R6II-8.

12. Weaver LC, Stein RD: Effects of spinal cord transection on sympathetic discharge in decerebrate-unanesthetized cats. Am J Physiol 1989, 257:RI506-II.

13. Zhong S, Huang ZS, Gebber GL, Barman SM: Role of the brain stem in generating the 2- to $6-\mathrm{Hz}$ oscillation in sympathetic nerve discharge. Am J Physiol 1993, 265:R 1026-35.

14. Kenney MJ, Pickar JG, Weiss ML, Saindon CS, Fels RJ: Effects of midbrain and spinal cord transections on sympathetic nerve responses to heating. Am J Physiol Regul Integr Comp Physiol 2000, 278(5):RI329-RI338.

15. Cervero F, Connell LA: Distribution of somatic and visceral primary afferent fibers within the thoracic spinal cord of the cat. J Comp Neurol 1984, 230:88-98.

16. Kuo DC, De Groat WC: Primary afferent projections of the major splanchnic nerve to the spinal cord and gracile nucleus of the cat. J Comp Neurol 1985, 23 I:421-34.

17. Weiss ML, Chowdhury SI: The renal afferent pathways in the rat: a pseudorabies virus study. Brain Res 1998, 8I 2:227-4I.

18. Strack AM, Sawyer WB, Hughes JH, Platt KB, Loewy AD: A general pattern of CNS innervation of the sympathetic outflow demonstrated by transneuronal pseudorabies viral infection. Brain Res 1989, 49 I: I56-62.

19. Cabot JB, Alessi V, Carroll J, Ligorio M: Spinal cord lamina V and lamina VII interneuronal projections to sympathetic preganglionic neurons. J Comp Neurol 1994, 347:5 I5-30.

20. Joshi S, Levatte MA, Dekaban GA, Weaver LC: Identification of spinal interneurons antecedent to adrenal sympathetic preganglionic neurons using trans-synaptic transport of herpes simplex virus type I. Neuroscience 1995, 65(3):893-903.

21. Tang $X$, Neckel ND, Schramm LP: Locations and morphologies of sympathetically correlated neurons in the TIO spinal segments of the rat. Brain Res 2003, 976:185-93.

22. Tang $X$, Neckel ND, Schramm LP: Spinal interneurons infected by renal injection of pseudorabies virus in the rat. Brain Res 2004, I 004: I-7.

23. Deuchars SA, Milligan CJ, Stornetta RL, Deuchars J: GABAergic neurons in the central region of the spinal cord: a novel substrate for sympathetic inhibition. I Neurosci 2005, 25(5): 1063-70.

24. Su C-K: Rhythmic sympathetic nerve discharges in an in vitro neonatal rat brainstem-spinal cord preparation. J Appl Physiol 1999, 87(3): 1066-75.

25. Purves $D$, Thompson $W$ : The effects of postganglionic axotomy on selective synaptic connexions in the superior cervical ganglion of the guinea pig. J Physiol 1979, 297:95-II0.

26. Kocsis B, Gyimesi-Pelczer K: Spinal segments communicating resting sympathetic activity to postganglionic nerves of the stellate ganglion. Am J Physiol 1998, 275(R44):R400-R09. 
27. Bullitt E: Expression of c-fos-like protein as a marker for neuronal activity following noxious stimulation in the rat. J Comp Neurol 1990, 296:517-30.

28. Fritschy JM, Frondoza CG, Grzanna R: Differential effects of reserpine on brainstem catecholaminergic neurons revealed by Fos protein immunohistochemistry. Brain Res 1991, 562(I):48-56.

29. Zhang Y-H, Lu J, Elmquist JK, Saper CB: Lipopolysaccharide activates specific populations of hypothalamic and brainstem neurons that project to the spinal cord. J Neurosci 2000, 20(I 7):6578-86

30. Chan SH, Chao YM, Tseng CJ, Chan JY: Down-regulation of basal Fos expression at nucleus tractus solitarii underlies restoration of baroreflex response after antihypertensive treatment in spontaneously hypertensive rats. Neuroscience 2002, I | 2: I | 3-20.

31. Cano G, Passerin AM, Schiltz JC, Card JP, Morrison SF, Sved AF: Anatomical substrates for the central control of sympathetic outflow to interscapular adipose tissue during cold exposure. J Comp Neurol 2003, 460:303-26.

32. Weston M, Wang H, Stornetta RL, Sevigny CP, Guyenet PG: Fos expression by glutamatergic neurons of the solitary tract nucleus after phenylephrine-induced hypertension in rats. J Comp Neurol 2003, 460:525-4I.

33. Nason MWJ, Mason P: Modulation of sympathetic and somatomotor function by the ventromedial medulla. I Neurophysiol 2004, 92(I):510-22

34. Stocker SD, Cunningham JT, Toney GM: Water deprivation increases Fos immunoreactivity in PVN autonomic neurons with projections to the spinal cord and rostral ventrolateral medulla. Am J Physiol Regul Integr Comp Physiol 2004, 287(5): RI I 72-83.

35. Fenwick NM, Martin CL, Llewellyn-Smith IJ: Immunoreactivity for cocaine- and amphetamine-regulated transcript in rat sympathetic preganglionic neurons projecting to sympathetic ganglia and the adrenal medulla. J Comp Neurol 2006, 495(4):422-33.

36. Chen HK, Su CK: Endogenous activation of nicotinic receptors underlies sympathetic tone generation in neonatal rat spinal cord in vitro. Neuropharmacology 2006, 5 I: I I 20-28.

37. Su C-K: Intraspinal amino acid neurotransmitter activities are involved in the generation of rhythmic sympathetic nerve discharge in newborn rat spinal cord. Brain Res 200I, 904: I I2-25.

38. Markham JA, Phelps PE, Vaughn JE: Development of rostrocaudal dendritic bundles in rat thoracic spinal cord: analysis of cholinergic sympathetic preganglionic neurons. Brain Res Dev Brain Res. I991, 6 I (2):229-236.

39. Lobo MV, Alonso FJ, Arenas MI, Caso E, Fraile B, del Rìo RM: Ultrastructural staining with sodium metaperiodate and sodium borohydride. J Histochem Cytochem 2002, 50(I): I I-I9.

40. Marina N, Morales T, Diaz N, Mena F: Suckling-induced activation of neural c-fos expression at lower thoracic rat spinal cord segments. Brain Res 2002, 954:100-14.

41. Minson J, Arnolda L, Llewellyn-Smith I, Pilowsky P, Chalmers J: Altered c-fos in rostral medulla and spinal cord of spontaneously hypertensive rats. Hypertension 1996, 27:433-4I.

42. Minson JB, Arnolda LF, Llewellyn-Smith IJ: Neurochemistry of nerve fibers apposing sympathetic preganglionic neurons activated by sustained hypotension. J Comp Neurol 2002, 449(4):307-18.

43. Paxinos G, Törk I, Tecott LH, Valentino KL: Atlas of the developing rat brain San Diego: Academic press; 1991.

44. Croning MD, Zetterstrom TS, Grahame-Smith DG, Newberry NR: Action of adenosine receptor antagonists on hypoxiainduced effects in the rat hippocampus in vitro. $\mathrm{Br} J$ Pharmacol 1995, I I 6(3):21 I3-9.

45. Schubert P, Ogata T, Marchini C, Ferroni S, Rudolphi K: Protective mechanisms of adenosine in neurons and glial cells. Ann $N Y$ Acad Sci 1997, 825: I- I0.

46. Kofuji $P$, Newman EA: Potassium buffering in the central nervous system. Neuroscience 2004, I 29:1045-56.

47. Greenberg ME, Ziff EB, Greene LA: Stimulation of neuronal acetylcholine receptors induces rapid gene transcription. Science 1986, 234:80-83.
48. Okada Y, Chen Z, Jiang W, Kuwana S-I, Eldridge FL: Anatomical arrangement of hypercapnia-activated cells in the superficial ventral medulla of rats. J Appl Physiol 2002, 93:427-39.

49. Dun NJ, Mo N: Inhibitory postsynaptic potentials in neonatal rat sympathetic preganglionic neurones in vitro. J Physiol 1989 , 410:267-81.

50. Spanswick D, Pickering AE, Gibson IC, Logan SD: Inhibition of sympathetic preganglionic neurons by spinal glycinergic interneurons. Neuroscience 1994, 62(I):205-16.

5I. Krupp J, Bordey A, Feltz P: Electrophysiological evidence for multiple glycinergic inputs to neonatal rat sympathetic preganglionic neurons in vitro. Eur / Neurosci 1997, 9(8): I7I I-9.

52. Giniatullin RA, Sokolova EM, Di Angelantonio S, Skorinkin A, Talantova MV, Nistri A: Rapid relief of block by mecamylamine of neuronal nicotinic acetylcholine receptors of rat chromaffin cells in vitro: an electrophysiological and modeling study. Mol Pharmacol 2000, 58(4):778-87.

53. Wilson JM, Coderre E, Renaud LP, Spanswick D: Active and passive membrane properties of rat sympathetic preganglionic neurones innervating the adrenal medulla. J Physiol 2002, 545(3):945-60.

54. Jansen AS, Wessendorf MW, Loewy AD: Transneuronal labeling of CNS neuropeptide and monoamine neurons after pseudorabies virus injections into the stellate ganglion. Brain Res 1995, 683:1-24.

55. Chau D, Johns DG, Schramm LP: Ongoing and stimulus-evoked activity of sympathetically correlated neurons in the intermediate zone and dorsal horn of acutely spinalized rats. J Neurophysiol 2000, 83:2699-707.

56. Barman SM, Gebber GL: Spinal interneurons with sympathetic nerve-related activity. Am J Physiol 1984, 247(5 Pt 2):R76I-7.

57. Deuchars SA, Brooke RE, Frater B, Deuchars J: Properties of interneurones in the intermediolateral cell column of the rat spinal cord: role of the potassium channel subunit KV3.I. Neuroscience 200I, 106(2):433-46.

58. Muller UW, Dembowsky K, Czachurski J, Seller H: Tonic descending inhibition of the spinal cardio-sympathetic reflex in the cat. J Auton Nerv Syst 1988, 23(2): I I I-I 23.

59. Cabot JB: Some principles of the spinal organization of the sympathetic preganglionic outflow. Prog Brain Res 1996, I 07:29-42.

60. Miller CO, Johns DG, Schramm LP: Spinal interneurons play a minor role in generating ongoing renal sympathetic nerve activity in spinally intact rats. Brain Res 2001, 918:101-06.

61. Schramm LP: Spinal sympathetic interneurons: Their identification and roles after spinal cord injury. Prog Brain Res 2006, I 52:27-37.

62. Ruggiero DA, Anwar M, Kim J, Sica AL, Gootman N, Gootman PM: Induction of c-fos gene expression by spinal cord transection in the rat. Brain Res 1997, 763:21-29.

63. Forehand C): Morphology of sympathetic preganglionic neurons in the neonatal rat spinal cord: an intracellular horseradish peroxidase study. J Comp Neurol 1990, 298:334-42.

64. Bogan N, Cabot JB: Light and electron microscopic analysis of intraspinal axon collaterals of sympathetic preganglionic neurons. Brain Res 1991, 541:24I-5I.

Publish with Bio Med Central and every scientist can read your work free of charge

"BioMed Central will be the most significant development for disseminating the results of biomedical research in our lifetime. "

Sir Paul Nurse, Cancer Research UK

Your research papers will be:

- available free of charge to the entire biomedical community

- peer reviewed and published immediately upon acceptance

- cited in PubMed and archived on PubMed Central

- yours - you keep the copyright
BioMedcentral 